International Journal of Current Advanced Research

ISSN: O: 2319-6475, ISSN: P: 2319 - 6505, Impact Factor: SJIF: 5.995

Available Online at www.journalijcar.org

Volume 6; Issue 3; March 2017; Page No. 2349-2350

DOI: http://dx.doi.org/10.24327/ijcar.2017.2350.0007

Research Article

\title{
A STUDY TO ASSESS THE EFFECTVINESS OF STRUCTURED TEACHING PROGRAMME ON KNOWLEDGE REGARDING ILL EFFECTS OF JUNK FOOD AMONG TEENAGE STUDENTS IN SELECTED SCHOOL, CHENNAI
}

\author{
*Hemavathy V., Girijabhaskaran and Rosy Sanasam
}

SreeBalaji College of Nursing, Bharath University Tamil Nadu, India

\section{A R T I C L E I N F O}

\section{Article History:}

Received $19^{\text {th }}$ December, 2016

Received in revised form $24^{\text {th }}$ January,

2017Accepted $12^{\text {th }}$ February, 2017

Published online $28^{\text {th }}$ March, 2017

\section{Key words:}

Structured teaching programme, ill effects of junk food, teenage students.

\begin{abstract}
A B S T R A C T
Street food and fast food are also taken in the same context as Junk. When we speak of street food, the fact that it's cooked in unhealthy conditions makes it more unhealthy than the same food made at home. Coming to the latter, fast food is the kind of food item which can be made and served quickly. The biggest irony regarding junk food is the fact that it's mostly prepared out of healthy food. Coming to Indian Junk food, locally called 'Chaat', these mostly include the Samosas, Kachoris, Panipuris/golgappas are fried items with various filling within an outer layer made of refined flour.In India, the consumer spending rate on processed food had increased at an average rate of $7.6 \%$ annually during the years 2008 to 2010 and this was expected to continue as the consumer expense would rise with an average of around $8.6 \%$ till the year 2012. 30\% of children aged 2-19 years are considered overweight or obese and has been estimated that 1 in 3 children born in the year 2000 will develop diabetes in their lifetime over the past 3 decades the childhood obesity rate has more doubled for pre-school children aged 2-5 years and adolescents aged 12-19 years and it has more tripled for children aged 6-11 years. Thus the present study aimed at evaluating the effectiveness of structured teaching programme on ill effects of junk food among teenage students of Hilton Matriculation Higher Secondary School, Chrompet, Chennai-44. The purpose of the study is to assess the knowledge among teenage students before and after administering planned teaching programmeregarding ill effects of junk food, to assess the effectiveness of planned teaching program among teenage students regarding ill effects of junk food and to associate the post-test knowledge score with selected demographic variables ofteenage students. The study method was evaluative research approach and a pre experimental one group pre-test and post-test research design was used. Non Randomized sampling technique was used to select the sample. The total samplewas 40 teenage students. Pre- test and post-test scores was assessed by using standardized questionnaires. The result of the study concluded that mean and standard deviation of knowledge level score in pre-test was 6.3 and 2.31 and post test score was 10.4 and 2.98 the calculated ' $t$ ' value was 11.4 which reveals that there was statistically highly significant difference between the pre-test and post-test score. It is evidenced that the planned teaching programme was significantly effective in improving knowledge regarding ill effects of junk food among teenage students.
\end{abstract}

Copyright@2017 Hemavathy V et al. This is an open access article distributed under the Creative Commons Attribution License, which permits unrestricted use, distribution, and reproduction in any medium, provided the original work is properly cited.

\section{INTRODUCTION}

Junk food is a term describing food that is perceived to be unhealthy or having poor nutritional value, according to Food Standards Agency. The term is believed to have been coined by Michael Jacobson, director of the centre for science in the public interest, in 1972. The term has since become common usage. Junk food includes those food items that do not add any value to a person's diet. Here value denotes essential nutrients, vitamins and minerals.

\section{*Corresponding author: Hemavathy $\mathbf{V}$}

SreeBalaji College of Nursing, Bharath University Tamil Nadu, India

\section{Objectives}

1. To assess the knowledge regarding ill effects of Junk food before structure teaching programme among teenage students in a selected school Chennai.

2. To evaluate the effectiveness of structure teaching programme among teenage students regarding ill effects of junk food

3. To compare the pre-test and post- test knowledge regarding ill effects of junk food among teenage students after structure teaching programme.

4. To find out the association between the post test knowledge scores with demographic variables. 

junk food among teenage students in selected school, Chennai

\section{METHODOLOGY}

Research design pre-experimental one group pre-test and post-test was adopted for the study. The research setting was at Hilton matriculation higher secondary school, Chennai-44 and Sample size was 40 teenage students selected by nonprobality convenient sampling technique.

\section{RESULT}

In pre- test majority of the students reveals $23(57.5 \%)$ have moderate knowledge, 5(12.5\%) adequate knowledge and $12(30 \%)$ inadequate knowledge about ill effects of junk food. reveals the post-assessment scores of the teenage students after the structured teachingprogramme on ill effects of junk food. Regarding the post- assessment, majority of the students $24(60 \%)$ gained adequate knowledge, 12(30\%) gained moderately adequate knowledge, 4(10\%) gained inadequate knowledge. The pre-test mean was 6.0 with standard deviation 2.31, and the post-test mean score was 10.4 with standard deviation 2.98 the obtained paired ' $t$ ' value was 11.4 which reveals there was statistically highly significant different between the pre-test and post-test at $\mathrm{P}<0.05$.Hence, the structured teaching programme regarding ill effects of junk food among teenage students is found effective.

All the demographic variables had no association with the post- test level of knowledge

\begin{tabular}{cccccc}
\hline $\begin{array}{c}\text { Overall } \\
\text { knowledge }\end{array}$ & Mean & $\begin{array}{c}\text { Mean } \\
\text { Difference }\end{array}$ & Sd & 't'Value & 'p'value \\
\hline $\begin{array}{c}\text { Pre test } \\
\text { Post test }\end{array}$ & $\begin{array}{c}\text { 10.3 } \\
\text { Pr.4 }\end{array}$ & 4.1 & 2.31 & 11.4 & $\mathrm{P}<0.05$ \\
\hline
\end{tabular}

\section{CONCLUSION}

The study concluded that majority of the students have gained moderately adequate knowledge after the structured teaching programme on ill effects of junk food. Furthermore educating the students regarding the ill effects of junk foods, the disease that are caused by junk foods, may help prevent the complication faced in the long run. As the students are the pillars of the future. Thus, educating them may help in building up a world free form disease.

\section{References}

1. Black M Joyce, H.J Keene MA, (2001) "Medical and SURGICAL Nursing", $6^{\text {th }}$ edition, Pennsylvania, Saunders Publishers.

2. Brunner and Suddarth's (2009), "Textbook of Medical Surgical Nursing", Volume 1, Eleventh edition, Philadelphia, Wolters Kluwer, Lippincott Williams \& Wilkins.

3. Lewis Heitkemper Dirksen, "Medical Surgical Nursing", $6^{\text {th }}$ edition, Mosby publishers, St.Louis.

4. Harmful effects of junk food.

5. Available from: http://www.healthyjunkie.com/ article. asparticleid=24566andharmful-effects-of-junkfood www.medline.com

Please cite this article in press as:

Hemavathy V., Girijabhaskaran and Rosy Sanasam (2017), A Study to Assess The Effectviness of Structured Teaching Programme on Knowledge Regarding Ill Effects of Junk Food Among Teenage Students In Selected School, Chennai, International Journal of Current Advanced Research, 6(3), pp. 2349-2350.

http://dx.doi.org/10.24327/ijcar.2017. 2350.0007 